\title{
CHLOROTETRACYCLINE AS AN INDICATOR OF THE INTERACTION OF CALCIUM WITH BRAIN MEMBRANE FRACTIONS
}

\author{
C. A. M. Carvalho \\ Centro de Biologia Celular, Departamento de Zoologia, Universidade de Coimbra, Coimbra, Portugal
}

(Received 2 June 1977. Revised 1 September 1977. Accepted 12 September 1977)

\begin{abstract}
The fluorescence of chlorotetracycline (CTC) in the presence of synaptosomes isolated from sheep brain is selectively increased by $\mathrm{Ca}^{2+}$ under conditions in which $\mathrm{Mg}^{2+}, \mathrm{Na}^{+}, \mathrm{K}^{+}, \mathrm{Li}^{+}$or choline have only a small effect. The monovalent cations release bound $\mathrm{Ca}^{2+}$ from synaptosomes, and this effect is reflected by a decrease in the CTC fluorescence. Under optimal conditions there is a near parallelism between $\mathrm{Ca}^{2+}$ and CTC binding to the synaptosomes membranes, and $\mathrm{Li}^{+}$is the monovalent cation tested which interferes the most with the binding of both substances. These results obtained in a predominantly sucrose medium become less distinct when media simulating physiological composition are utilized, which limits the usefulness of the method. Brain mitochondria and myelin also bind $\mathrm{Ca}^{2+}$ and CTC. The ratio of the fluorescence signal (or CTC bound) to $\mathrm{Ca}^{2+}$ bound is highest of all for mitochondrial membranes, and the apparent fluorescence quantum yield of CTC is also the highest in these membranes, which suggests that the $\mathrm{Ca}^{2+}$ in these membranes is localized in a more apolar region than is the case for synaptosomes and myelin.
\end{abstract}

Chlorotetracycline (CTC) has been utilized recently as a probe to follow $\mathrm{Ca}^{2+}$ movements in biological membranes (CASWELl \& HUTCHISON, 1971; Caswell, 1972; Schuster \& Olson, 1973; luthra \& Olson, 1976; Hallet et al., 1972; Caswell \& WaRREN, 1972; SchafFer \& Olson, 1976; CaRValho \& Carvalho, 1976a, $b$; Carvalho \& Carvalho, 1977). The principle of utilization of CTC to detect bound $\mathrm{Ca}^{2+}$ to biological membranes resides in the fact that CTC preferentially forms a complex with $\mathrm{Ca}^{2+}$ bound to the membrane phase. There is an increase in the fluorescence signal (CASWELL \& HuTCHISON, 1971) of CTC when it binds to the membrane (Carvalho \& Carvalho, 1976a, $b$; Carvalho \& Carvalho, 1977; Schuster \& Olson, 1973; SCHAFFER \& OLSON, 1976).

The role of $\mathrm{Ca}^{2+}$ in regulating neural activity and the release of neurotransmitters is widely recognized (Blaustein, 1974; BAKER, 1972; RAHAMmofF et al., 1975), and recently several reports have appeared on the effect of $\mathrm{K}^{+}, \mathrm{Li}^{+}$and $\mathrm{Na}^{+}$on the fluxes and membrane binding of $\mathrm{Ca}^{2+}$ in synaptosomes (BLAUSTEIN \& OBORN, 1975; Blaustein \& ECTOR, 1976; BlausteIn, 1974; ICHIDA et al., 1976) along with other reports on the interactions of $\mathrm{Ca}^{2+}$ with various brain membrane fractions (LAZAREWICZ et al., 1974; SWANSON et al., 1974; HEMMINKI, 1974; KRISHNAN \& Balaram, 1976; Kamino et al., 1974; Kamino et al., 1975a, $b$; KAMINO, 1976).

We have recently utilized the CTC fluorescence

Abbreviation used: CTC, chlorotetracycline. technique for monitoring qualitatively $\mathrm{Ca}^{2+}$ interaction with membranes of sarcoplasmic reticulum (CARValHo \& CaRvalho, 1976a, $b ;$ 1977) with good results. This report contains the results of experiments in which the applicability of the CTC fluorescence technique to monitor the interaction of $\mathrm{Ca}^{2+}$ and other cations with synaptosomes, myelin and mitochondria isolated from sheep brain was explored. The results show that under optimal conditions the technique is relatively selective for $\mathrm{Ca}^{2+}$ over $\mathrm{Mg}^{2+}$ and that the release of $\mathrm{Ca}^{2+}$ bound to synaptosomes induced by $\mathrm{Na}^{+}, \mathrm{K}^{+}$and $\mathrm{Li}^{+}$is reflected by a decrease in CTC fluorescence.

\section{METHODS AND MATERIALS}

Preparation of subcellular fractions from brain tissue. Sheep brain cortex was fractionated by differential and density gradient centrifugation in sucrose solutions according to the method described by WhITTAKER et al. (1964). The three fractions collected from the gradients (myelin, synaptosomes and mitochondria) were washed once with $310 \mathrm{~mm}$-sucrose containing $20 \mathrm{~mm}$-Tris $-\mathrm{Cl}$ at $\mathrm{pH} 7.4$. and were resuspended in the same medium at a protein concentration of $20 \mathrm{mg} / \mathrm{ml}$. The protein concentration was determined by the biuret method described by LAYNE (1957)

Incubation of synaptosomes and other brain fractions with chlorotetracycline in various media. Synaptosomes were incubated at room temperature in various media as described in the legends of figures, and usually contained $310 \mathrm{~mm}$-sucrose and/or monovalent cations, buffered with $20 \mathrm{~mm}$-Tris- $\mathrm{HCl}$ at $\mathrm{pH}$ 7.4. Chlorotetracycline (CTC) was added at a concentration of $25 \mu \mathrm{M}$. and synaptosomes were kept at $0.4 \mathrm{mg}$ of protein $/ \mathrm{ml}$. When present, $\mathrm{CaCl}_{2}$ was 
added at $1 \mathrm{~mm}$ final concentration. The fluorescence changes of CTC due to $\mathrm{Ca}^{2+}$ were measured in $2.5 \mathrm{ml}$ samples containing $1.0 \mathrm{mg}$ of protein with a Perkin-Elmer Model MPF-3 spectrofluorometer with the excitation and emission wavelengths at $400 \mathrm{~nm}$ and $520 \mathrm{~nm}$, respectively. In preliminary experiments it was shown that concentrations of CTC below $30 \mu \mathrm{M}$ do not affect the binding of $\mathrm{Ca}^{2+}$ by the membranes, as was also shown by SCHAFFER \& OLSON (1976).

The binding of $\mathrm{Ca}^{2+}$ and CTC to the membranes was measured under the same experimental conditions used in the fluorimetric measurements. The samples $(5 \mathrm{ml}$ containing $2 \mathrm{mg}$ of protein) were either filtered through Millipore filters, or were centrifuged at $13,000 \mathrm{~g}$ for $20 \mathrm{~min}$. In the experiments using filtration, the filters with the protein were washed twice with $2.0 \mathrm{ml}$ of $310 \mathrm{~mm}$-sucrose buffered with $20 \mathrm{~mm}$-Tris- $\mathrm{HCl} \mathrm{pH} \mathrm{7.4}$, and then were eluted with $2 \mathrm{ml}$ of $4 \%$ TCA. $0.5 \% \mathrm{La}^{3+}$ and $4 \mathrm{~mm}-\mathrm{CsCl}$. The eluate was analysed for $\mathrm{Ca}^{2+}$ and $\mathbf{M g}^{2+}$ by atomic absorption spectrophotometry. In the cases in which the membrane suspensions were centrifuged, the supernatants were kept for CTC analysis and the pellets were rinsed twice and re-suspended in $1.0 \mathrm{ml}$ of de-mineralised water. These protein suspensions were treated with $4 \%$ TCA containing $1 \%$ $\mathrm{La}^{3+}$ and $4 \mathrm{~mm}-\mathrm{CsCl}$, and after short centrifugation in a bench centrifuge the supernatants were analysed for $\mathrm{Ca}^{2+}$ and $\mathrm{Mg}^{2+}$ by atomic absorption spectrophotometry, as described previously by Carvalho \& Leo (1967). The bound CTC was calculated by difference between the total CTC added to the incubation medium and the free CTC remaining in the supernatant after $13,000 \mathrm{~g}$ centrifugation, and was measured by the method described by SCHUSTER \& OLSON (1973).

Incubation of synaptosomes in complex physiological media. Some experiments were performed by transferring the synaptosomal membranes to a complex physiological medium containing $20 \mathrm{~mm}$-Tris, $10 \mathrm{~mm}$-glucose, $1.2 \mathrm{~mm}$ $\mathrm{NaH}_{2} \mathrm{PO}_{4}, 1.3 \mathrm{~mm}-\mathrm{MgCl}_{2}, 7 \mathrm{~mm}$-maleic acid to a final $\mathrm{pH}$ of $7.4,137 \mathrm{~mm}$ of either $\mathrm{NaCl}, \mathrm{LiCl}, \mathrm{KCl}$ or choline chloride, $25 \mu \mathrm{M}-\mathrm{CTC}$ and $0.4 \mathrm{mg}$ of protein $/ \mathrm{ml}$. When added. $\mathrm{CaCl}_{2}$ was at a concentration of $1.0 \mathrm{~mm}$. Fluorescence measurements, $\mathrm{Ca}^{2+}$ and CTC binding to synaptosomes were performed in these experiments as described in the previous section.

Reagents. Chlorotetracycline was purchased from Sigma Chemical Company and solutions at pH 7.4 were prepared freshly every day. All the other reagents were of analytical grade.

\section{RESULTS}

Changes in the fuorescence of chlorotetracycline during $\mathrm{Ca}^{2+}$ and $\mathrm{Mg}^{2+}$ interaction with the synaptosomal membranes

The results shown in Fig. 1 demonstrate that the interaction of $\mathrm{Ca}^{2+}$ or $\mathrm{Mg}^{2+}$ with synaptosomes causes an increase in the fluorescence of chlorotetracycline. Figure $\mid$ also shows that CTC fluorescence nearly parallels the binding of $\mathrm{Ca}^{2+}$ or $\mathrm{Mg}^{2+}$ by the membranes. After a rapid initial increase in cation binding and fluorescence during the first $15 \mathrm{~s}$, a slower further increase occurs in the case of $\mathrm{Ca}^{2+}$, but not of $\mathrm{Mg}^{2+}$. At $5 \mathrm{~min}$ after adding the divalent cations, the $\mathrm{Ca}^{2+}$ and $\mathrm{Mg}^{2+}$ binding are $35 \mathrm{nmol}$ of $\mathrm{Ca}^{2+} / \mathrm{mg}$

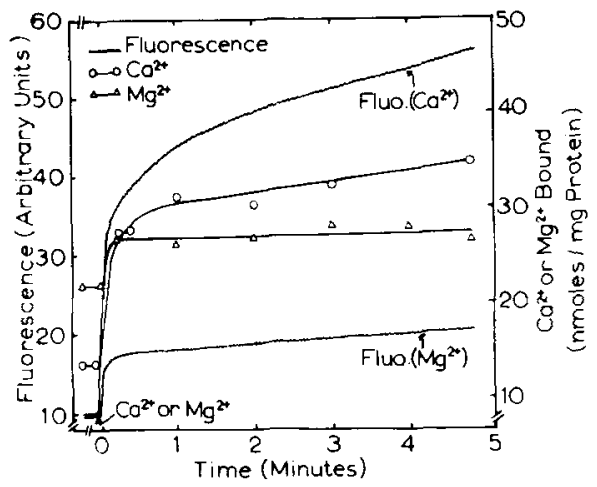

FIG. 1. Chlorotetracycline-associated fluorescence changes during $\mathrm{Ca}^{2+}$ or $\mathrm{Mg}^{2+}$ interaction with the membranes of sheep brain synaptosomes. The incubation medium con-

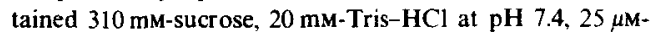
chlorotetracycline, $0.4 \mathrm{mg}$ protein per $\mathrm{ml}$, and the reaction was started by adding $1 \mathrm{~mm}-\mathrm{CaCl}_{2}$ or $\mathrm{MgCl}_{2} \cdot \mathrm{Ca}^{2+}$ and $\mathrm{Mg}^{2+}$ binding to the membranes was measured by Millipore filtration as described in Methods.

of protein and $30 \mathrm{nmol}$ of $\mathrm{Mg}^{2+} / \mathrm{mg}$ of protein, but the fluorescence change induced by $\mathrm{Ca}^{2+}$ is about 6-fold higher than that induced by $\mathrm{Mg}^{2+}$ (Fig. 1).

Effect of various cations on the fluorescence of chlorotetracycline in synaptosomes

In order to determine the relative effect of various monovalent and divalent cations on the CTC fluorescence in synaptosomes, titrations of CTC in synaptosomal suspensions were performed with increasing cation concentrations. Figure 2 depicts the enhancement of fluorescence due to the addition of membranes to the various media containing $25 \mu \mathrm{M}$-CTC. The fluorescence of the probe in the suspending

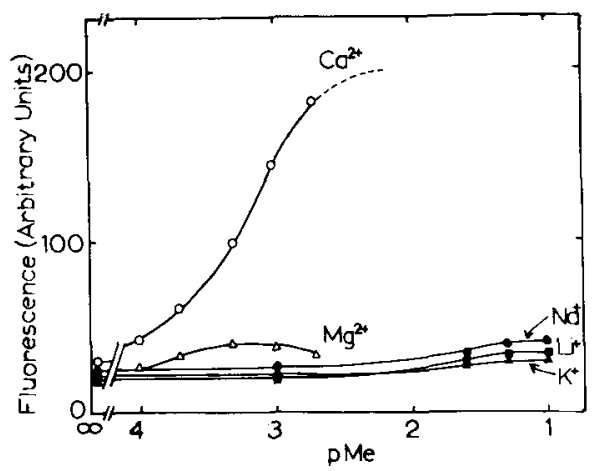

Fig. 2. Effect of monovalent and divalent cations on the fluorescence of chlorotetracycline in synaptosomes. Reaction media contained $310 \mathrm{~mm}$-sucrose, $20 \mathrm{~mm}-\mathrm{Tris}-\mathrm{Cl} \mathrm{pH}$ 7.4, $25 \mu \mathrm{m}$-chlorotetracycline, $0.4 \mathrm{mg}$ synaptosomal protein per $\mathrm{ml}$ and various concentrations of cations as indicated in the abscissa as pMe (-log molarity). Fluorescence intensities were corrected for the fluorescence of chlorotetracycline observed in the absence of the synaptosomes. 

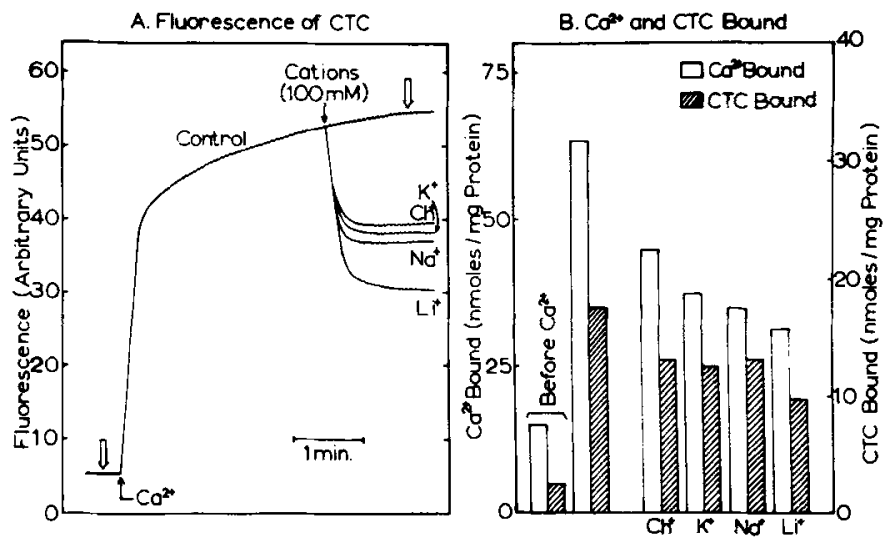

FIG. 3. Effect of the monovalent cations, $\mathrm{Na}^{+}, \mathrm{K}^{+}, \mathrm{Li}^{+}$or choline $\left(\mathrm{Ch}^{+}\right)$on the interaction of $\mathrm{Ca}^{2+}$ with synaptosomes, as measured by the effect on the fluorescence (Part A) and on the binding of CTC and $\mathrm{Ca}^{2+}$ to the membranes (Part B). Synaptosomes $(0.4 \mathrm{mg}$ of protein $/ \mathrm{ml}$ ) were incubated in $310 \mathrm{~mm}$-sucrose plus $20 \mathrm{~mm}$-Tris- $\mathrm{Cl} \mathrm{pH} \mathrm{7.4.} \mathrm{Ca}^{2+}$ or monovalent cations were added as indicated in the traces. $\mathrm{Ca}^{2+}$ and CTC binding were measured after centrifugation as described in Methods.

media without protein added, together with membrane turbidity, were subtracted. Monovalent cations $\left(\mathrm{Na}^{+}, \mathrm{K}^{+}\right.$, or $\left.\mathrm{Li}^{+}\right)$do not significantly alter the fluorescence of CTC even at concentrations as high as $100 \mathrm{~mm}$. Divalent cations, $\mathrm{Ca}^{2+}$ and $\mathrm{Mg}^{2+}$, have different effects on the fluorescence, $\mathrm{Ca}^{2+}$ being the more efficient one in increasing the fluorescence. $\mathrm{Mg}^{2+}$ increases the fluorescence of the basic medium containing $\mathrm{CTC}$, in the absence of synaptosomes, much more than does $\mathrm{Ca}^{2+}$ (results not shown). Thus, CTC is a much more sensitive probe for detecting the interaction of synaptosomes with $\mathrm{Ca}^{2+}$ than with $\mathrm{Mg}^{2+}$. The large background fluorescence of CTC in media containing $\mathrm{Mg}^{2+}$ in the absence of membranes should be taken in consideration when CTC is to be used to follow $\mathrm{Ca}^{2+}$ interactions with synaptosomal membranes in media containing $\mathrm{MgCl}_{2}$ (Blaustein \& Ector, 1976).

Although monovalent cations do not alter the CTC fluorescence, they are effective in significantly reducing the fluorescence increase due to the interaction of $1 \mathrm{mM}-\mathrm{Ca}^{2+}$ with the membranes. Figure 3 shows this effect for $\mathrm{Na}^{+}, \mathrm{Li}^{+}, \mathrm{K}^{+}$and choline (100 mM) when added after $\mathrm{Ca}^{2+}$ interaction with the membranes. Either of these monovalent cations decreases the fluorescence signal, but $\mathrm{Li}^{+}$is the most efficient in this respect (Fig. 3A). The effects of the cations on the CTC and $\mathrm{Ca}^{2+}$ binding (Fig. 3B) are approximately parallel to the effect on the CTC fluorescence. It is observed that $\mathrm{Li}^{+}$is the cation which releases the most $\mathrm{Ca}^{2+}$ from the membranes; it decreases the level from about $65 \mathrm{nmol}$ to about $35 \mathrm{nmol} / \mathrm{mg}$ of protein. In the case of $\mathrm{Li}^{+}$the binding of CTC is also maximally decreased from 17.5 to $10 \mathrm{nmol}$ of $\mathrm{CTC} / \mathrm{mg}$ of protein. The higher $\mathrm{Ca}^{2+}$ binding observed in this experiment, in comparison with the results in Fig. 1, is due to the fact that the centrifugation method, without washing of the pellet, was util- ized, whereas in the experiments reported in Fig. 1 the $\mathrm{Ca}^{2+}$ binding was obtained by the filtration technique with washing of the filters. Therefore, the values for $\mathrm{Ca}^{2+}$ binding reported in Fig. 3 are maximal values.

Figure 4 represents the effect of $\mathrm{Ca}^{2+}$ on the fluorescence of CTC in synaptosomes previously incubated in a complex physiological medium containing $\mathrm{MgCl}_{2}$, among other substances, and either $\mathrm{Na}^{+}, \mathrm{K}^{+}$, $\mathrm{Li}^{+}$or choline $(137 \mathrm{~mm})$. The objective in this experiment was to study the interaction of $\mathrm{Ca}^{2+}$ with synaptosomes in a physiological medium using this fluorimetric method. Such media are usually utilized in physiological studies in which synaptosomes are used as model systems (BLAuSTEIN \& ECTOR, 1976). It is observed in Fig. $4 \mathrm{~A}$ that the fluorescence increase due to $\mathrm{Ca}^{2+}$ addition to the synaptosomes suspended in this complex medium is much lower than the increase observed when the membranes are incubated in a sucrose medium in the absence of cations. It is also observed that the basal fluorescence before $\mathrm{Ca}^{2+}$ addition is very high in comparison with that observed in sucrose medium (Fig. 3A). This must be related with the high $\mathrm{Mg}^{2+}$ concentration in the incubation medium. The results showing $\mathrm{Ca}^{2+}$ and CTC binding are represented in Fig. 4B. It is observed that the total $\mathrm{Ca}^{2+}$ in the membranes increased from about 7 to 10 to 25 to $30 \mathrm{nmol}$ per $\mathrm{mg}$ of protein in all the media upon $\mathrm{Ca}^{2+}$ addition. Although significant differences appear to exist in the $\mathrm{Ca}^{2+}$ binding, it is difficult to quantify these differences by the fluorescence changes which, nevertheless, give qualitative information (Fig. 4A). The higher fluorescence level after $\mathrm{Ca}^{2+}$ addition for the media containing $\mathrm{K}^{+}$or $\mathrm{Na}^{+}$corresponded to a higher CTC binding to the membranes (Fig. 4A). Upon $\mathrm{Ca}^{2+}$ addition the binding of $\mathrm{Mg}^{2+}$ is only slightly decreased, so that the predominant effect on the fluorescence is caused 


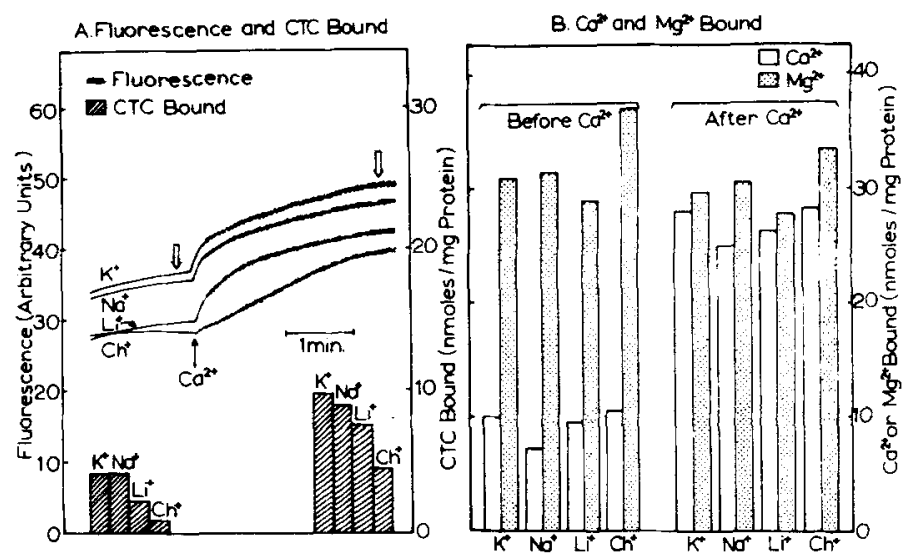

Fig. 4. Response of the fluorescence of chlorotetracycline and of $\mathrm{Ca}^{2+}, \mathrm{Mg}^{2+}$ and CTC binding to $\mathrm{Ca}^{2+}(1 \mathrm{~mm})$ addition when synaptosomes are incubated in complex physiological media. Synaptosomes were incubated at a concentration of $0.4 \mathrm{mg}$ of protein $/ \mathrm{ml}$ in media containing $20 \mathrm{~mm}$-Tris, $10 \mathrm{mM}$-glucose, $1.2 \mathrm{~mm}-\mathrm{NaH}_{2} \mathrm{PO}_{4}, 1.3 \mathrm{mM}-\mathrm{MgCl}_{2}, 7 \mathrm{~mm}$-maleic acid to a final $\mathrm{pH}$ of $7.4,137 \mathrm{~mm}$ of either $\mathrm{NaCl}$, $\mathrm{LiCl}, \mathrm{KCl}$ or choline chloride and $25 \mu \mathrm{M}$-chlorotetracycline. The sensitivity of the fluorimeter, after $\mathrm{Ca}^{2+}$ addition $(\mathrm{mm})$, was set at a value three times higher than before $\mathrm{Ca}^{2+}$ addition $(-)$. In part $A$ the traces show the fluorescence of CTC developed in these media and the bars represent the binding of CTC in the various media measured at the points indicated by the arrows before and after $\mathrm{Ca}^{2+}$ additions. In part $\mathrm{B}, \mathrm{Ca}^{2+}$ and $\mathrm{Mg}^{2+}$ bound to the membranes at the points indicated by the arrows before and after $\mathrm{Ca}^{2+}$ addition to the medium, respectively, is shown.

by $\mathrm{Ca}^{2+}$ binding which increases significantly (Fig. 4B).

In complex physiological medium the ratio of increase in CTC fluorescence to increased $\mathrm{Ca}^{2+}$ binding is much lower than observed when the experiments are performed in the non-ionic medium of sucrose.

Interaction of chlorotetracycline and $\mathrm{Ca}^{2+}$ with various brain fractions

In this section we present results of experiments in which we examined the interaction of $\mathrm{Ca}^{2+}$ with myelin, synaptosomes and mitochondria isolated from the same brain tissue, by following the changes in the CTC-associated fluorescence in these membrane systems. In all the systems studied the addition of $1 \mathrm{mM}-\mathrm{CaCl}_{2}$ to a membrane suspension in sucrose promotes a rapid fluorescence increase followed by a slower increase until a maximal fluorescence is attained a few minutes after $\mathrm{Ca}^{2+}$ addition (Fig. 5). However, the total fluorescence increase is much

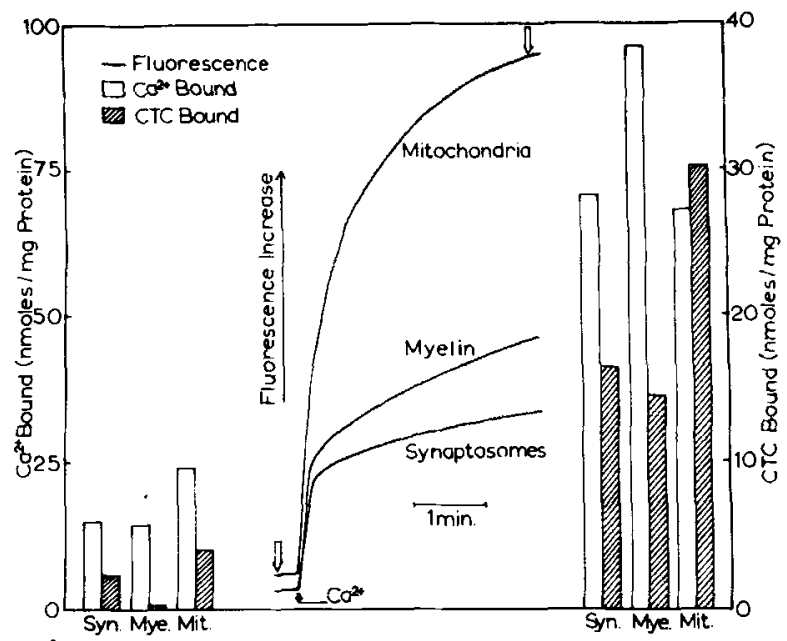

FIG. 5. Effect of $\mathrm{Ca}^{2+}$ on the fluorescence of chlorotetracycline in various brain fractions. The fractions ( $0.4 \mathrm{mg}$ of protein $/ \mathrm{ml}$ ) were incubated in $310 \mathrm{~mm}$-sucrose, $20 \mathrm{~mm}$-Tris- $\mathrm{Cl} \mathrm{pH} 7.4$ and $25 \mu \mathrm{M}$-chlorotetracycline. At the center of the figure is shown the change in chlorotetracycline fluorescence upon addition of $1 \mathrm{mM}-\mathrm{CaCl}_{2}$. The bars represent $\mathrm{Ca}^{2+}$ and chlorotetracycline binding to the membranes at the arrows before $\mathrm{Ca}^{2+}$ addition and at maximal $\mathrm{Ca}^{2+}$ induced fluorescence, respectively. 
higher in the case of mitochondria than it is in the other two cases for the same membrane protein concentrations.

The results depicted in Fig. 5 also show the levels of $\mathrm{Ca}^{2+}$ and CTC binding before $\mathrm{Ca}^{2+}$ addition (bars at the left of Fig. 5) and 5 min. after $\mathrm{Ca}^{2+}$ interaction with the membranes (bars at the right of Fig. 5). The most striking difference between the three fractions is the higher CTC binding attained 5 min after $\mathrm{Ca}^{2+}$ addition in the case of mitochondria. This was about $30 \mathrm{nmol} \mathrm{CTC}$ bound $/ \mathrm{mg}$ of mitochondrial protein, as compared with 17 and $14 \mathrm{nmol} / \mathrm{mg}$ of protein in synaptosomes and myelin, respectively. The ratio of CTC bound to $\mathrm{Ca}^{2+}$ bound is also higher in mitochondria than in the other two fractions (Fig. 5).

In order to further elucidate the difference between the fluorescence of CTC in these three membrane fractions, the possible differences in the quantum yield of CTC fluorescence in these membranes were investigated. In these experiments the CTC concentration was maintained constant $(25 \mu \mathrm{M})$ and the amount of membrane protein was varied. Figure 6 is a doublereciprocal plot of fluoresœence vs membrane protein concentration which shows rectilinearity for low protein concentrations, but reaches a limiting value for higher protein concentrations. Extrapolating the lines obtained to the $y$-axis, the intercept gives the maximal fluorescence $\left(F_{\max }\right)$ of CTC in the membranes, which is an indication of the quantum yield of the probe in the membranes. Comparison of the values for $F_{\max }$ obtained for the three membrane systems tested $\left(F_{\max }=35,60\right.$ and 100 respectively, for myelin, synaptosomes and mitochondria) reveals that the quantum yield of CTC is higher for the mitochondrial membranes than it is for the other two membrane systems. The results suggest that the higher fluorescence observed in Fig. 5 for mitochondrial membranes is

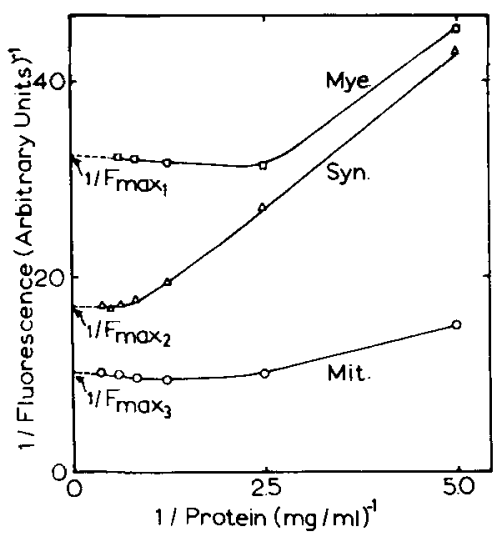

FIG. 6. Alteration in fluorescence intensity of chlorotetracycline in myelin (Mye.), synaptosomes (Syn.) and brain mitochondria (Mit.) as a function of protein concentration. Fluorescence was measured in a medium $(2.5 \mathrm{ml})$ containing $310 \mathrm{~mm}$-sucrose, $20 \mathrm{~mm}$-Tris $\mathrm{Cl} \mathrm{pH} 7.4,1 \mathrm{~mm}-\mathrm{CaCl}_{2}$, $25 \mu \mathrm{M}$-chlorotetracycline and protein concentrations between 0 and $2.4 \mathrm{mg} / \mathrm{ml}$. Excitation and emission were 400 and $520 \mathrm{~nm}$, respectively. Fluorescence values are corrected for turbidity due to protein addition determined in the absence of chlorotetracycline. The calculated $F_{\max }$ values are: $F_{\max 1}=35, F_{\max 2}=60$ and $F_{\max 3}=100$ fluorescence units as determined from the intercepts at the ordinates. The scale at the ordinates is multiplied by $10^{3}$.

due to a higher probe binding per $\mathrm{mg}$ of protein and also to an increase in quantum yield of the probe when it reacts with these membranes (Fig. 6). Figure 6 shows that the quantum yield of CTC is lower in the myelin membranes than in the synaptosomes, but the fluorescence observed for protein concentrations of the order of those utilized in Fig. $5(1 \mathrm{mg})$ is only slightly higher for the myelin than for the synaptosomes. This difference is accentuated at higher protein
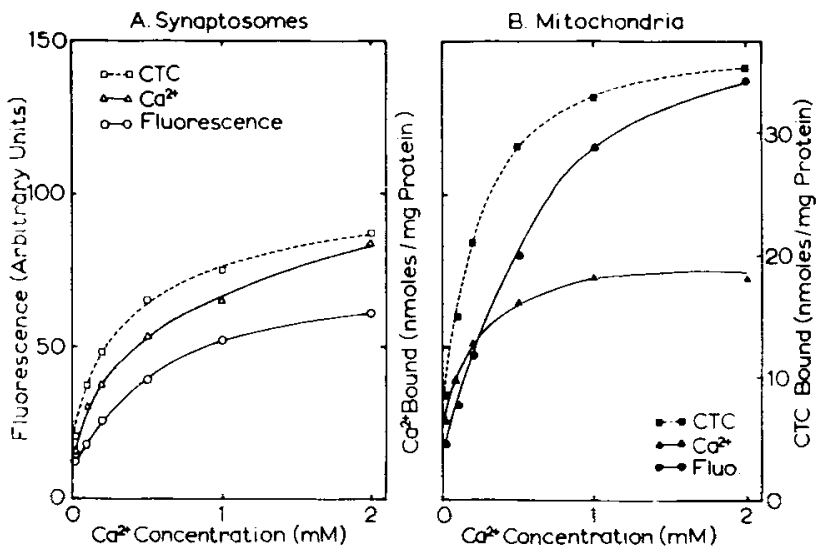

Fig. 7. Effect of increasing $\mathrm{Ca}^{2+}$ concentrations on the fluorescence of chlorotetracycline and $\mathrm{Ca}^{2+}$ binding to synaptosomes and brain mitochondria. The membranes $(0.4 \mathrm{mg}$ of protein $/ \mathrm{ml})$ were incubated as described in the legend of Fig. 5, except that the $\mathrm{Ca}^{2+}$ concentration was varied from 0 to $2 \mathrm{~mm}$. $\mathrm{Ca}^{2+}$ binding was measured after 5 minutes of incubation with $\mathrm{Ca}^{2+}$, and $\mathrm{Ca}^{2+}$ analysis was carried out on the centrifuged pellet by the procedure described in Methods. The scale for CTC binding in $A$ is the same as that specified in $B$. The scale for $\mathrm{Ca}^{2+}$ binding in $B$ is that specified in $A$. 
concentrations because the CTC fluorescence reaches a maximal value in the presence of myelin at protein concentrations which are insufficient to produce maximal fluorescence in the presence of synaptosomes (Fig. 6).

The results in Fig. 7 show the effect of increasing $\mathrm{CaCl}_{2}$ concentrations $(0-2 \mathrm{~mm})$ on the fluorescence and on the $\mathrm{Ca}^{2+}$ and $\mathrm{CTC}$ binding to the membranes of synaptosomes (Part A) or mitochondria (Part B). The effect of $\mathrm{Ca}^{2+}$ on the parameters studied attains near saturation for both synaptosomes and mitochondria at a concentration of $2 \mathrm{~mm}-\mathrm{CaCl}_{2}$, and it is confirmed that for all the concentrations studied the fluorescence of CTC is higher in the case of mitochondria than in the case of synaptosomes. The higher fluorescence observed in mitochondrial membranes correlates well with a higher CTC binding (Fig. 7), although about the same amount of $\mathrm{Ca}^{2+}$ is bound to both membrane systems. The affinity of membrane bound $\mathrm{Ca}^{2+}$ for CTC is probably higher in the case of mitochondria than it is in the case of synaptosomes, which probably reflects different environments for the $\mathrm{Ca}^{2+}$ bound in the two membrane systems (Caswell \& Hutchison, 1971 $a, b$; Caswell, 1972).

\section{DISCUSSION}

The results presented show that the interaction of $\mathrm{Ca}^{2+}$ with synaptosomes and other brain fractions can be followed utilizing CTC fluorescence. The fluorescence intensity of the probe increases upon $\mathrm{Ca}^{2+}$ addition to the suspending medium containing synaptosomes, and there is a parallel increase in $\mathrm{Ca}^{2+}$ and CTC binding by the synaptosomes (Figs. 1-3). Similar results were already described for these (SCHAFFER \& OLSON, 1976) and other membrane systems (CASWELL \& Warren, 1972; LaU et al., 1974; Caswell, 1972; SChuster \& Olson, 1973; Schuster \& Olson, 1974; Caswell \& Hutchison, 1971; Carvalho \& CarVALHO, 1977). The method is relatively specific for $\mathrm{Ca}^{2+}$ over $\mathrm{Mg}^{2+}$. Thus, the binding of $\mathrm{Ca}^{2+}$ produces a much higher fluorescence signal than the binding of a corresponding amount of $\mathrm{Mg}^{2+}$ (Figs. 1 and 2). Apparentiy, the affinity constant for the interaction between CTC and divalent cations is selectively increased for $\mathrm{Ca}^{2+}$ by an apolar medium such as found in the membrane phase (CAswell \& HuTChison, 1971; Caswell, 1972; Hallett et al., 1972).

Another observation in Fig. 1 is that, upon $\mathbf{C a}^{2+}$ addition to the synaptosomes, and after the initial phase of rapid increase in fiuorescence, there is a gradual increase in the fluorescence which is accompanied by a gradual increase in $\mathrm{Ca}^{2+}$ binding to the membranes. This increase in $\mathrm{Ca}^{2+}$ binding with time is probably due to entry of $\mathrm{Ca}^{2+}$ to more internal binding sites which is then followed by CTC binding. This phenomenon is not observed with $\mathbf{M g}^{2+}$.

As shown in Fig. 2, monovalent cations $\left(\mathrm{Na}^{+}, \mathrm{K}^{+}\right.$ and $\mathrm{Li}^{+}$) do not directly affect the fluorescence of CTC in the synaptosomes, but they significantly de- crease the fluorescence induced by $\mathrm{Ca}^{2+}$, as was reported recently for the case of $\mathrm{Na}^{+}$(SCHAFFER \& Olson, 1976). This effect is due to the loss of $\mathrm{Ca}^{2+}$ and CTC from the membranes induced by the monovalent cations, which is most prominent for the case of $\mathrm{Li}^{+}$(Fig. 3B).

The results presented in Fig. 4 show the fluorescent signal of CTC obtained when $\mathrm{Ca}^{2}+$ is added to a synaptosomal suspension in complex physiological media similar to that utilized by BLAustein \& ECTOR (1976). Such media contain, in addition to $\mathrm{Mg}^{2+}$ and other ions, either $\mathrm{K}^{+}, \mathrm{Na}^{+}, \mathrm{Li}^{+}$or choline. When CTC is added to these media, the initial fluorescence is already relatively high and there is a small fluorescence response to addition of $\mathrm{Ca}^{2+}$, even though the $\mathrm{Ca}^{2+}$ binding increases significantly (Fig 4). Apparently, the various cations in the suspending medium inhibit or quench the CTC fluorescence normally induced by $\mathrm{Ca}^{2+}$ binding to synaptosomes. These observations indicate that the utilization of CTC fuorescence to follow $\mathrm{Ca}^{2+}$ interaction with synaptosomes is of limited application for studies when physiological conditions are simulated. The results presented in Fig. 5 show that myelin and mitochondria also take up CTC upon $\mathrm{Ca}^{2+}$ addition. As in the case of synaptosomes the uptake of $\mathrm{Ca}^{2+}$ and CTC is due to the passive interaction of $\mathrm{Ca}^{2+}$ and CTC with the membranes, since no energy source is present. Thus, we are not following the energy dependent uptake of $\mathrm{Ca}^{2+}$ by mitochondria as was reported for liver mitochondria by LUTHRA \& OLSON (1976). Nevertheless, it is of interest that the passive interaction of $\mathrm{Ca}^{2+}$ with brain mitochondria promotes a higher CTC binding than does the interaction of $\mathrm{Ca}^{2+}$ with either of other two fractions, although about the same amount of $\mathrm{Ca}^{2+}$ is bound to synaptosomes and mitochondria. This higher affinity of membrane bound $\mathrm{Ca}^{2+}$ for CTC probably reflects that the $\mathrm{Ca}^{2+}-\mathrm{CTC}$ complex, which forms in the mitochondrial membranes, must be sensing a different environment. This is probably more apolar than in the case of the other two membrane systems, myelin and synaptosomes. In these systems bound $\mathrm{Ca}^{2+}$ may be located more superficially, where the affinity for CTC in this relatively polar environment would be diminished (CASWELL \& HuTCHISON, 1971)

The results presented show that CTC fluorescence is useful in following $\mathrm{Ca}^{2+}$ interactions with three membrane systems isolated from sheep brain in a simple non-physiological medium of isotonic sucrose In this medium the effects of monovalent cations on $\mathrm{Ca}^{2+}$ binding are readily followed by monitoring CTC fluorescence changes associated with the complex formed between $\mathrm{Ca}^{2+}$ bound and CTC in the membrane phase. These effects of monovalent cations on $\mathrm{Ca}^{2+}$ transfer between the medium and the membrane phase should be distinguished from those reported by other workers (BLAustein \& Ector, 1976; Blaustein \& OBORN, 1975; Blaustein \& Wiesman, 1970; ICHIDA et al. 1976) and which 
apparently reflect transmembrane fiuxes of $\mathrm{Ca}^{2+}$. The fluorescence technique is somewhat more limited in its application to follow movements of $\mathrm{Ca}^{2+}$ in membranes suspended in complex physiological media which produce initial high CTC fluorescence.

Acknowledgements--I am grateful to Professors A. P. Carvalho and V. M. C. Madeira for many useful discussions and suggestions during the course of this work. This research was supported by I.N.I.C., the Portuguese National Institute for Scientific Research.

\section{REFERENCES}

Baker P. F. (1972) Prog. Biophys. Molec. Biol. 24, 177-223. Blaustein M. P. (1974) Rev. Physiol. Biochem. Pharmacol. 70, 34-81.

Blaustein M. P. \& Ector A. C. (1976) Biochim. biophys. Acta 419, 295-308.

Blaustein M. P. \& Oborn C. J. (1975) J. Physiol. Lond 247, 657-686

Blaustein M. P. \& Wiesmann W. P. (1970) Proc. natn Acad. Sci. U.S.A. 66, 664-671.

Carvalho A. P. \& Leo B. (1967) J. gen. Physiol. 50, 1327-1352.

Carvalho C. A. M. \& Carvalho A. P. (1976a) Cienc. Biol., Portugal 2, 223-238.

Carvalho C. A. M. \& Carvalho A. P. (1976b) Cienc Biol., Portugal 2, 239-253.

Carvalho C. A. M. \& Carvalho A. P. (1977) Biochim biophys. Acta 468, 21-30.

Caswell A. H. (1972) J. Membrane Biol. 7, 345-364.

Caswell A. H. \& Hutchison J. D. (1971a) Biochem. biophys. Res. Commun. 42, 43-49.

Caswell A. H. \& Hutchison J. D. (1971b) Biochem. biophys. Res. Commun. 43, 625 630.
Caswell A. H. \& Warren S. (1972) Biochem. biophys. Res. Commun. 46, 1757-1763.

Hallett M., Schneider A. S. \& Carbone E. (1972) $J$. Membrane Biol. 10, 31-44.

Hemmink! K. (1974) Biochim. biophys. Acta 363, 202-210. Ichida S., Hata F. \& Matsuda T. (1976) Jap. J. Pharmac 26, 31-37.

Kamino K., Uyesaka N. \& Inouye A. (1974) $J$. Membrane Biol. 17, 13-26.

Kamino K., Inouye K., Ogawa M., Uyesaka N. \& INOUYE A. (1975a) J. Membrane Biol. 23, 21-31.

Kamino K., Uyesaka N., Ogawa M. \& Inouye A. (1975b) J. Membrane Biol. 21, 113-124.

Kamino K., Ogawa M., Uyesaka N. \& Inouye A. (1976) J. Membrane Biol. 26, 345-356.

Krishnan K. S. \& Balaram P. (1976) Archs Biochem. Biophys. 174, 420-430

lau Y. H., Chiv T. H., Caswell A. M. \& Potter L. T. (1974) Biochem. biophys. Res. Commun. 61, 510-516. LAYNE E. (1957) Meth. Enzym. 3, 447-454.

LaZarewicz J. W., Haljamae.H. \& Hamberger A. (1974) J. Neurochem. 22, 33-45.

Luthra R. \& Olson M. S. (1976) Biochim. biophys, Acta 440, 744-758

Rahamimoff R., Rahamimoff H., Binah O. \& Meiri U (1975) in Calcium Transport in Contraction and Secretion (Carafoli E., Clementi F., Drabikowski W. \& MarGRETH A., eds.), pp. 253-260. North-Holland, Amsterdam.

SCHAFFER W. T. \& OLSON M. S. (1976) J. Neurochem. 27, 1319-1325

SChuster S. M. \& Olson M. S. (1973) J. biol. Chem. 248, 8370-8377.

SCHUSTer S. M. \& OLSON M. S. (1974) J. biol. Chem. 249. $7151-7158$.

SWANSON P. D., ANDerson L. \& Stahl W. L. (1974) Biochim. biophys. Acta 356, 174-183.

Whittaker V. P.. Michaelson I. A. \& Kirkland R. J. A. (1964) Biochem. J. 90, 293-303. 